\title{
Increased Cerebral Blood Flow after single dose of antipsychotics in healthy volunteers depends on dopamine $\mathrm{D} 2$ receptor density profiles.
}

Pierluigi Selvaggi ${ }^{1}$, Peter C.T. Hawkins ${ }^{1}$, Ottavia Dipasquale ${ }^{1}$, Gaia Rizzo ${ }^{2,3}$, Alessandro Bertolino $^{4}$, Juergen Dukart ${ }^{5}$, Fabio Sambataro ${ }^{6}$, Giulio Pergola ${ }^{4}$, Steven C.R. Williams ${ }^{1}$, Federico Turkheimer ${ }^{1}$, Fernando Zelaya ${ }^{1}$, Mattia Veronese ${ }^{1 *}$ and Mitul A. Mehta ${ }^{1 *}$

${ }^{1}$ Department of Neuroimaging, Institute of Psychiatry, Psychology and Neuroscience, King's College London, London, United Kingdom

${ }^{2}$ Invicro, London, UK

${ }^{3}$ Division of Brain Sciences, Department of Medicine, Imperial College London, London, UK

${ }^{4}$ Department of Basic Medical Science, Neuroscience and Sense Organs, University of Bari Aldo Moro, Bari, BA, Italy

${ }^{5}$ F. Hoffmann-La Roche, pharma Research Early Development, Roche Innovation Centre Basel, Basel, Switzerland

${ }^{6}$ Department of Experimental and Clinical Medical Sciences, University of Udine, Udine, Italy

*Designated equal contribution as senior author.

Corresponding author: Pierluigi Selvaggi

Centre for Neuroimaging Sciences

Institute of Psychiatry, Psychology \& Neuroscience

King's College London

De Crespigny Park; SE5 8AF; London, UK

pierluigi.selvaggi@kcl.ac.uk

Running title: D2 receptors and antipsychotics effects on cerebral blood flow

Keywords: CBF, Antipsychotics, ASL, PET, $\mathrm{D}_{2} \mathrm{R}$, mRNA expression, DRD2 


\begin{abstract}
As a result of neuro-vascular coupling, the functional effects of antipsychotics in human brain have been investigated in both healthy and clinical populations using haemodynamic markers such as regional Cerebral Blood Flow (rCBF). However, the relationship between observed haemodynamic effects and the pharmacological action of these drugs has not been fully established. Here, we analysed MRI-based rCBF data from a placebo-controlled study in healthy volunteers, who received a single dose of three different D2 receptor antagonists and tested the association of the main effects of the drugs on $\mathrm{rCBF}$ against normative population maps of $\mathrm{D}_{2} \mathrm{R}$ protein density and gene-expression data. In particular, we correlated $\mathrm{CBF}$ changes after antipsychotic administration with non-displaceable binding potential $\left(\mathrm{BP}_{\mathrm{ND}}\right)$ template maps of the high affinity $\mathrm{D}_{2}$-antagonist Positron Emission Tomography (PET) ligand $\left[{ }^{18} \mathrm{~F}\right]$ Fallypride and brain post-mortem microarray mRNA expression data for the $D R D 2$ gene. For all antipsychotics, $\mathrm{rCBF}$ changes were directly proportional to brain $\mathrm{D}_{2} \mathrm{R}$ densities and DRD2 mRNA expression measures, although PET $\mathrm{BP}_{\mathrm{ND}}$ spatial profiles explained more variance as compared with mRNA profiles (PET $\mathrm{R}^{2}$ range $=0.20-0.60$, mRNA PET $\mathrm{R}^{2}$ range 0.04-0.20, pairwise-comparisons all $\mathrm{p}<0.05$ ). In addition, the spatial coupling between $\triangle \mathrm{CBF}$ and $\mathrm{D}_{2} \mathrm{R}$ profiles varied between the different antipsychotics tested, possibly reflecting differential affinities. Overall, these results indicate that the functional effects of antipsychotics as measured with $\mathrm{rCBF}$ are tightly correlated with the distribution of their target receptors in striatal and extra-striatal regions. Our results further demonstrate the link between neurotransmitter targets and haemodynamic changes reinforcing $\mathrm{rCBF}$ as a robust in-vivo marker of drug effects. This work is important in bridging the gap between pharmacokinetic and pharmacodynamics of novel and existing compounds.
\end{abstract}




\section{Introduction}

Antipsychotics are still the preferred choice for the treatment of conditions such as schizophrenia and other mental health disorders with psychotic features (Stroup et al, 2009). The main target of most of these compounds is the dopamine $\mathrm{D}_{2}$ receptor $\left(\mathrm{D}_{2} \mathrm{R}\right)$ (Burt et al, 1977; Farde et al, 1986) where they act as antagonists or partial agonists. $\mathrm{D}_{2} \mathrm{R}$ occupancy of antipsychotics has been assessed in vivo with emission tomography in healthy controls and clinical populations (Agid et al, 2007; Kapur et al, 1995; Nyberg et al, 1995) and it has also been linked with treatment response (Kapur et al, 2000). While antipsychotics have been well characterized in terms of their pharmacokinetics (PK) and clinical response, their impact on brain physiology and function is still not well understood. A deeper understanding of these effects is crucial to uncover biological mechanisms driving their clinical efficacy as well as their side effects.

Functional effects of antipsychotics in the brain have been investigated using different neuroimaging tools. Seminal work using Positron Emission Tomography (PET) $\left[{ }^{18} \mathrm{~F}\right]$ fluorodeoxyglucose and $\left[{ }^{15} \mathrm{O}^{\mathrm{H}} \mathrm{H}_{2} \mathrm{O}\right.$ showed that drug naïve first episode psychosis patients, had increased glucose utilization after treatment with antipsychotics (DeLisi et al, 1985; Holcomb et al, 1996) and greater perfusion (Goozee et al, 2014; Miller et al, 1997; 2001) in the basal ganglia. Similar results were also obtained in healthy volunteers using a single dose of antipsychotics (Kim et al, 2013; Mehta, 2003). Studies using Arterial Spin Labelling (ASL), a Magnetic Resonance Imaging (MRI) sequence designed to quantitatively measure regional cerebral blood flow $(\mathrm{rCBF})$, found results in line with the earlier PET studies. In particular, (Fernández-Seara et al, 2011) reported increased rCBF in the striatum and thalamus in healthy volunteers after a single oral dose of $10 \mathrm{mg}$ of metoclopramide (a $\mathrm{D}_{2} \mathrm{R}$ antagonist) and (Handley et al, 2013) showed that both haloperidol $3 \mathrm{mg}\left(\mathrm{a} \mathrm{D}_{2} \mathrm{R}\right.$ 
antagonist) and aripiprazole $10 \mathrm{mg}$ (a $\mathrm{D}_{2} \mathrm{R}$ partial agonist with 5-HT2a antagonism properties) increased $\mathrm{rCBF}$ in the striatum in healthy volunteers with a larger effect size for haloperidol. Recently, we tested the effects of a single clinical effective dose of different antipsychotics (Hawkins et al, 2018). Consistent with the existing literature, $3 \mathrm{mg}$ haloperidol, $2 \mathrm{mg}$ risperidone and $0.5 \mathrm{mg}$ risperidone increased striatal $\mathrm{rCBF}$ as compared with placebo.

One of the major limitations of pharmacological MRI studies stands on the haemodynamic nature of the main functional measures (e.g. BOLD and rCBF). According to the neurovascular coupling model (Attwell and Iadecola, 2002; Logothetis et al, 2001) changes in haemodynamic MRI measures reflect a complex cascade of cellular, metabolic and vascular events associated with changes in neuronal activity (Heeger and Ress, 2002; Hoge et al, 1999; Singh, 2012). In line with this model, the main effects of drug may be interpreted as the result of dose-dependent enhanced or reduced pre- or post-synaptic activity due to the action of the drug on its targets (Khalili-Mahani et al, 2017). Although many antipsychotics bind to numerous receptors, the effects on rCBF have been tacitly attributed to $\mathrm{D}_{2} \mathrm{R}$ blockade. In particular, $\mathrm{D}_{2} \mathrm{R}$ antagonism would lead to enhanced neurotransmitter turnover in the dopaminergic synapses inducing metabolic activity and therefore perfusion demands (Goozee et al, 2014; Handley et al, 2013). The findings of altered dopamine synthesis capacity after acute antipsychotics administration in human volunteers and rats support this hypothesis (Hertel et al, 1996; Ito et al, 2009; Vernaleken et al, 2008). However, since MRI does not measure neuronal activity directly, making a link between neuro-receptor binding and haemodynamic effects of these compounds requires a degree of conjecture. In addition, in the case of dopaminergic drugs, MRI hemodynamic changes have also been related to non-neuronal mechanisms including the action of $\mathrm{D}_{1}$-like receptors on vessels and $\mathrm{D}_{2}$-like receptors on perivascular astrocytes (Choi et al, 2006; Krimer et al, 1998). For these 
reasons, despite the body of evidence, the neurochemical mechanisms underlying $\mathrm{CBF}$ changes after antipsychotics administration remain unclear. The use of multimodal approaches, e.g. combining MR measures with ex-vivo autoradiography (Dukart et al, 2018), have started to fill this gap of knowledge.

Receptor occupancy theory posits that the magnitude of the drug response is a function of receptor availability (Clark, 1970; Ploeger et al, 2009). In other words, incremental changes in functional response correspond to increments of the fraction of receptors bound. This relationship also depends on specific characteristics of each compound, such as receptor affinity (i.e. $\mathrm{K}_{\mathrm{i}}$ ). This basic pharmacology principle has been used to characterize the spatial profile of drug effects in the brain (also called "drug fingerprinting") assuming that brain regions with high density of the target receptor will show higher magnitude of drug effects (Khalili-Mahani et al, 2017). This approach has been proposed to describe MRI changes to dopaminergic drugs in preclinical data (Mandeville et al, 2013). Indeed, a monotonic increase in $\mathrm{rCBF}$ has been observed following injection of an increasing dose of the $\mathrm{D}_{2} / \mathrm{D}_{3}$ antagonist radiotracer $\left[{ }^{11} \mathrm{C}\right]$ raclopride in the striatum of two male rhesus macaques (Sander et al, 2013). Interestingly, $\left[{ }^{11} \mathrm{C}\right]$ raclopride non-displaceable binding potential changes $\left(\mathrm{BP}_{\mathrm{ND}}\right)$ reflecting changes in $D_{2} / D_{3}$ receptor occupancy, correlated with the amplitude of hemodynamic changes (i.e. $\mathrm{rCBF}$ ): the higher the dose the larger $\mathrm{rCBF}$ increase; and in time: $\mathrm{BP}_{\mathrm{ND}}$ variation and changes in $\mathrm{rCBF}$ showed similar temporal profiles. The same group also found an inverse relationship between receptor occupancy and $\mathrm{rCBF}$ with the selective $\mathrm{D}_{2} / \mathrm{D}_{3}$ agonist quinpirole in male rhesus macaques (i.e. rCBF decrease in face of dose-dependent increase of receptor occupancy) (Sander et al, 2016a). Both studies provide evidence for a neurovascular coupling mechanism linking $M R$ haemodynamic changes and $D_{2} / D_{3}$ receptors pharmacological modulation in non-human primates although they are limited to the striatal region. 
The aim of the present work is to test in humans whether rCBF changes induced by a single dose of different antipsychotics co-varies with in vivo measures of $\mathrm{D}_{2} \mathrm{R}$ distribution. In particular, we employed two datasets from healthy volunteers (Hawkins et al, 2018) to evaluate the spatial correlation between $\mathrm{rCBF}$ variation in the placebo vs antipsychotic comparison against the population-based receptor density profiles derived from human PET scans using the high affinity $\mathrm{D}_{2} / \mathrm{D}_{3}$ antagonist $\left[{ }^{18} \mathrm{~F}\right]$ Fallypride (Mukherjee et al, 1995). We also investigated the same relationship at the gene expression level using post-mortem mRNA expression measures of $D R D 2$ (the gene coding for $\mathrm{D}_{2} \mathrm{R}$ ) extracted from the Human Allen Brain Atlas (ABA) (Hawrylycz et al, 2012a). Brain mRNA expression variation across brain regions has been shown to be associated with resting state fMRI networks suggesting that brain hemodynamic response may be linked to the architecture of the human brain transcriptome (Hawrylycz et al, 2015; Richiardi et al, 2015). Here, brain microarray mRNA expression data was chosen as a proxy to protein-level receptor density in the human brain. In fact, while post-transcriptional events may alter the relationship between gene expression and protein synthesis (Liu et al, 2016), brain mRNA expression maps have been shown to predict in vivo proteins level as measured with PET (Beliveau et al, 2017; Rizzo et al, 2014).

Following the receptor occupancy theory and the neurovascular coupling model proposed by (Sander et al, 2013) we hypothesized that there will be a detectable linear relationship between main effects of antipsychotics on CBF measures and $D_{2} R$ receptor density profiles evaluated at the protein and gene expression level. Even though brain microarray mRNA expression data from the $\mathrm{ABA}$ is noisier and more discrete (i.e. limited number of samples) than the PET $\mathrm{BP}_{\mathrm{ND}}$ maps, we expect $\mathrm{CBF}$ increases after antipsychotics to be linearly associated also with $D R D 2$ mRNA expression spatial profiles. However, given the fact that mRNA expression only approximates cellular protein levels due to post- 
bioRxiv preprint doi: https://doi.org/10.1101/336933; this version posted June 2, 2018. The copyright holder for this preprint (which was not certified by peer review) is the author/funder, who has granted bioRxiv a license to display the preprint in perpetuity. It is made available under aCC-BY-NC-ND 4.0 International license.

transcriptional regulatory mechanisms we predict microarray data to explain less variance in CBF changes than PET derived maps. 


\section{Materials and Methods}

\section{Participants and study design}

Data were collected as part of a project approved by the National Research Ethics Service Committee London - Brent (REC reference: 13/LO/1183). Details about participants, protocol and study design have been described in detail in (Hawkins et al, 2018). Briefly, forty-two healthy male subjects were enrolled in a double-blind, placebo-controlled, randomised, fully counterbalanced, three-session crossover design. Participants were randomised into two equal parallel study groups (Group 1 age mean/SD 27.6/6.9; Group 2 age mean/SD 28.3/6.3). In the first group participants received placebo, $7.5 \mathrm{mg}$ of olanzapine (OLA), or $3 \mathrm{mg}$ of haloperidol (HAL) on each study day. In the second group, participants received placebo, 0.5 or $2 \mathrm{mg}$ risperidone (lowRIS and highRIS respectively). All but lowRIS dosage were chosen in order to achieve on average at least $60 \%$ of D2 receptor occupancy (Kapur et al, 2000; Tauscher et al, 2004). On dosing day, participants followed a standardised regime. The MRI scan was performed at the time of predicted peak level of plasma concentration of the drug after oral administration $\left(\mathrm{T}_{\max }\right)$ : approximately 5 hours after drug administration for Group 1 and 2 hours for Group 2 (de Greef et al., 2011; Midha et al., 1989; Nyberg et al., 1997; Tauscher et al., 2002). Study days were seven days apart to allow washout between sessions. After the final visit, a follow-up phone call was made to monitor potential adverse events related to the study drugs.

\section{MRI acquisition and pre-processing}

All scans were conducted on a GE MR750 3 Tesla scanner using a 12-channel head coil. ASL image data were acquired using a 3D pseudo-continuous ASL sequence (3DpCASL) 
with a multi-shot, segmented 3D stack of axial spirals (8-arms) readout with a resultant spatial resolution (after re-gridding and Fourier Transformation) of 2x2x3mm. Four controllabel pairs were used to derive a perfusion weighted difference image. The labelling RF pulse had a duration of $1.5 \mathrm{~s}$ and a post-labelling delay of $1.5 \mathrm{~s}$. The sequence included background suppression for optimum reduction of the static tissue signal. A proton density image was acquired in $48 \mathrm{~s}$ using the same acquisition parameters in order to compute the CBF map in standard physiological units (ml blood/100g tissue/min). Pre-processing of all CBF data was performed exactly as described in Hawkins et al, (2018) (for further details please see Supplementary Materials).

\section{Receptor density profiles}

Figure 1 shows the general framework of the analysis. $D_{2} R$ profiles where extracted from an independent $\left[{ }^{18} \mathrm{~F}\right]$ Fallypride PET template obtained by averaging six binding potential $\left(\mathrm{BP}_{\mathrm{ND}}\right)$ whole brain maps acquired in healthy young volunteers (age range: 18-30 years) who did not participate in the drug study (Dunn et al, 2009). $\left[{ }^{18} \mathrm{~F}\right]$ Fallypride is a $\mathrm{D}_{2} / \mathrm{D}_{3}$ receptor antagonist and it is a well-established PET radiotracer in the study of $\mathrm{D}_{2}$-like receptor distribution in the brain (Mukherjee et al, 1995). Compared with other $\mathrm{D}_{2}$-like antagonist radiotracers (e.g. $\left[{ }^{11} \mathrm{C}\right]$ raclopride), $\left[{ }^{18} \mathrm{~F}\right]$ Fallypride has higher affinity and higher signal-tonoise ratios in vivo and therefore provides reliable quantitative measures of $\mathrm{D}_{2} \mathrm{R}$ concentration including extra-striatal brain regions (Mukherjee et al, 2002; Stark et al, 2018).

The $\left[{ }^{18} \mathrm{~F}\right]$ Fallypride template was segmented with the Desikan-Killiany Atlas (Desikan et al, 2006) and for each of the 85 Regions of Interest (ROIs) of the template, the voxel-wise mean $\mathrm{BP}_{\mathrm{ND}}$ value was extracted with the flslmeants function implemented in the Functional Software Library suite (FSL, FMRIB, Oxford, UK). Conventional parametric modelling of regional $\mathrm{BP}_{\mathrm{ND}}$ was performed by using the cerebellum as reference region (Ichise et al, 
2003). Therefore, both left and right cerebellar ROIs (namely "rh_cerebellum_cortex" and "lh_cerebellum_cortex") were excluded from correlation analyses with CBF profiles. To compare the contribution of striatal vs extra-striatal regions to this association, we also extracted $\mathrm{BP}_{\mathrm{ND}}$ profiles from a $\left[{ }^{11} \mathrm{C}\right]$ raclopride template obtained from a matchted group of healthy controls (Grecchi et al, 2014) (see Supplementary Material).

\section{CBF profiles}

CBF profiles were obtained from maps of CBF changes at the group level. In particular, for each antipsychotic, a group-wide paired T-test was performed in SPM12 for each drug vs placebo. Whole brain total blood flow was added as a covariate of no interest in the model to account for peripheral (global) drug effects and between-subjects variability in global brain perfusion (Handley et al, 2013; Viviani et al, 2009; 2013). In agreement with previous studies (Handley et al, 2013; Hawkins et al, 2018), we identified statistically significant increases in $\mathrm{CBF}$ after drug administration (against placebo) and have thus focussed on this contrast in the remainder of this work. Therefore, DRUG $>$ PLACEBO contrast maps for each antipsychotic where segmented by using the Desikan-Killiany Atlas (Desikan et al, 2006) using the same approach used for the extraction of receptor profiles. This resulted in 85 $\triangle \mathrm{CBF}$ profiles measuring the antipsychotic induced increase of $\mathrm{CBF}$ in each ROI. For consistency with the receptor profile data, we carried out correlation analyses excluding the two cerebellum ROIs.

\section{Statistical analysis for the $\Delta \mathrm{CBF} /$ receptor density profiles correlations}

To test the associations between $\triangle \mathrm{CBF}$ profiles (derived for each antipsychotic) and $\mathrm{D}_{2} / \mathrm{D}_{3}$ receptor density profiles, linear regression models as implemented in SPSS were used (IBM, SPSS Statistics, Version 23). Normal distribution of the residuals of the regression models 
were tested by Shapiro-Wilk test. $\mathrm{BP}_{\mathrm{ND}}$ data were transformed using a natural logarithmic function (ln) so that the residuals conformed to a normal distribution. For all linear regression models Mahalanobis distance and Cook's distance were computed in order to explore the presence of multivariate outliers and estimate the presence of highly influential data points. To identify multivariate outliers, Mahalanobis distance values were compared to a chi-square distribution with degrees of freedom equal to the number of variables (two in this case) with p= 0.001 (Finch, 2012; Tabachnick and Fidell, 2013). Any data point with Cook's distance higher than 1 was considered as highly influential outlier and excluded from the analysis (Cook and Weisberg, 1982). Non-parametric Spearman's correlations between $\Delta$ CBF profiles and receptor $\mathrm{BP}_{\mathrm{ND}}$ profiles were also performed as a countercheck. In addition, Fisher's r-to$\mathrm{z}$ transformation was performed to test pairwise significance of the difference between correlation coefficients of $\triangle \mathrm{CBF}$ profiles between different antipsychotics. Asymptotic covariance method was adopted to account for the fact that correlations had one variable in common (Lee and Preacher, 2013)

\section{mRNA profiles and genetic correlations}

$D R D 2$ gene brain microarray mRNA expression values were extracted from ABA data (http://human.brain-map.org) by using the Multimodal Environment for Neuroimaging and Genomic Analysis (MENGA) toolbox (http://www.nitrc.org/projects/menga/) (Rizzo et al, 2016). The same toolbox was used to carry out correlations with $\triangle \mathrm{CBF}$ profiles of each antipsychotic. First, antipsychotics' contrast images (DRUG $>$ PLACEBO) were resampled in the ABA space. Then, each CBF image sample was spatially matched with the corresponding genomic ABA sample within a search window of a sphere of $5 \mathrm{~mm}$ radius centred on the MNI coordinates of the ABA sample. Both $\mathrm{CBF}$ contrast image and $\mathrm{ABA}$ data were then segmented using the list of structures $(\mathrm{N}=169)$ provided by the ABA (Hawrylycz et al, 
2012b). A subset of 89 structures (ROIs), each containing at least one genomic sample for all the six ABA brains (donors), was selected to perform correlations between $\triangle \mathrm{CBF}$ profiles and gene expression. After completing the matching and the extraction of $\triangle \mathrm{CBF}$ and gene expression profiles, two different correlations were performed: 1) between-donors correlation or gene auto-correlation returning the biological variability of the spatial profile of mRNA expression between donors (the higher the gene autocorrelation the lower the heterogeneity in mRNA expression spatial profile between donors); 2) correlation between each gene expression and the $\triangle \mathrm{CBF}$ by ROIs also called cross-correlation. A Principal Component Analysis (PCA) on mRNA expression measures of the 6 ABA donors was performed beforehand in order to extract the component that accounted at least for the $95 \%$ of the total variance in the mRNA expression data. In particular, the PCA was performed on an $89 \times 6$ matrix (89 ROIs by 6 donors) and represented a consistent spatial mRNA expression profile across all donors. This component was then used in the regression model against CBF profiles. Significance was assessed with a bootstrapping approach resulting in a chance likelihood of the correlation coefficient expressed as a \%. More specifically, ROIs were permuted within donors repeating the correlation between PCA component and CBF profiles 1,000 times, in order to obtain a measure of the likelihood that the correlation found was different from chance level. A multivariate spatial correlation using MENGA was also performed between DRD2 gene expression profiles and $\left[{ }^{18} \mathrm{~F}\right] \mathrm{Fallypride} \mathrm{BP}_{\mathrm{ND}}$ maps. As for protein density profile analysis, Fisher's r-to-z transformation was performed to test pairwise significance of the difference between correlation coefficients of $\Delta \mathrm{CBF}$ profiles between different antipsychotics and also between PET and mRNA profiles.

[Figure 1 about here]

[General framework of the analyses] 


\section{Results}

\section{CBF changes with $\mathrm{D}_{2}$ receptor profiles correlations}

All antipsychotic $\triangle \mathrm{CBF}$ profiles significantly correlated with $\left[{ }^{18} \mathrm{~F}\right]$ Fallypride $\mathrm{BP}_{\mathrm{ND}}$ template values (Table 1 and Figure 2). HAL $\triangle \mathrm{CBF}$ had the strongest correlation with $\left[{ }^{18} \mathrm{~F}\right]$ Fallypride $\mathrm{BP}_{\mathrm{ND}}\left(\mathrm{R}_{\text {linear }}=0.78\right)$ followed by RIS ( $\mathrm{R}_{\text {linear }}=0.73$ and $\mathrm{R}_{\text {linear }}=0.72$ for lowRIS and highRIS respectively $)$ and OLA $\left(\mathrm{R}_{\text {linear }}=0.48\right)$. Results from linear models and non-parametric Spearman correlations were consistent. In all linear regressions, none of the data points were identified as a highly influential outlier (all Cook's distances> 1) or multivariate outliers (all Mahalanobis distances $p>0.01$ ). The rank of order and $R_{\text {linear }}$ values matched the variation in affinity with $\mathrm{D}_{2}$ receptor (McCormick et al, 2010), with the stronger the association between $\Delta \mathrm{CBF}$ profiles and $\mathrm{D}_{2}$ receptor densities the lower the Ki (Table 1 and Figure $\mathrm{S} 2$ ). In the pairwise correlation comparisons we found significant difference for HAL vs OLA $(z=5.46)$, lowRIS vs OLA $(\mathrm{z}=4.19)$ and vs highRIS vs OLA $(\mathrm{z}=3.90)\left(\right.$ all $\mathrm{p}_{\text {two-tailed }}<0.01$, Bonferroni corrected, Figure S2). All the other comparisons were not significant. To compare striatal vs extra-striatal contributions to this association we also performed correlations between $\triangle \mathrm{CBF}$ and receptor density profiles by extracting $\mathrm{BP}_{\mathrm{ND}}$ values from a $\left[{ }^{11} \mathrm{C}\right]$ raclopride $\mathrm{PET}$ template. We found weaker correlation with $\left[{ }^{11} \mathrm{C}\right]$ raclopride $\mathrm{BP}_{\mathrm{ND}}$ as compared with $\left[{ }^{18} \mathrm{~F}\right]$ Fallypride $\mathrm{BP}_{\mathrm{ND}}$ (see Supplementary Material).

[Table 1 about here]

[Figure 2 about here] 


\section{mRNA expression correlations}

The average correlation coefficient $\left(\mathrm{R}^{2}\right)$ of the genomic autocorrelation analysis for the DRD2 gene was 0.575 (standard deviation $=0.058$ ) for the six donors. This result indicated good stability between donors of DRD2 mRNA expression spatial profile (Rizzo et al, 2016). For the different antipsychotic drugs, the correlation coefficients were all positive and statistically significant (Figure 3 and Table 1) and also significantly lower than those obtained for the PET template $\left(\mathrm{PET} \mathrm{R}^{2}\right.$ range $=0.20-0.60$; mRNA PET $\mathrm{R}^{2}$ range 0.04-0.20; pairwise-comparisons all $\mathrm{p}<0.05)$. As for the correlation with $\left[{ }^{18} \mathrm{~F}\right] \mathrm{Fallypride}$ values, genomic mRNA expression correlations qualitatively mirrored Ki differences (McCormick et al, 2010) between antipsychotics at $\mathrm{D}_{2} \mathrm{R}$ (Figure $\mathrm{S} 2$ ). However, none of the pairwise comparisons between correlation coefficients between antipsychotics were statistically significant after correction for multiple comparisons.

[Figure 3 about here]

[Genomic analysis] 


\section{Discussion}

The aim of the present study was to investigate the relationship between the effects of single clinical effective doses of antipsychotics on $\mathrm{rCBF}$ and receptor distribution profiles in the brain as indexed by $\left[{ }^{18} \mathrm{~F}\right]$ Fallypride $\mathrm{BP}_{\mathrm{ND}}$ values and brain $D R D 2$ mRNA expression profiles. Consistently with our hypothesis, we found that for all compounds there was a spatial coupling between drug-induced $\mathrm{CBF}$ changes and $\mathrm{D}_{2}$ receptor density profiles (at both protein and gene expression level). In addition, we found that mRNA data explained less variance in $\mathrm{CBF}$ changes than PET derived map.

\section{Receptor density profiles}

The association between $\mathrm{CBF}$ changes induced by all antipsychotics and receptor brain spatial distribution of $\mathrm{D}_{2} \mathrm{R}$ matches earlier evidence in non-human primates showing large CBF increases after injection of the $\mathrm{D}_{2}$ antagonist PET tracer $\left[{ }^{11} \mathrm{C}\right]$ raclopride in brain regions with high $\mathrm{D}_{2} \mathrm{R}$ density (Sander et al, 2013). This suggests that the relationship between the physiological response to $\mathrm{D}_{2} \mathrm{R}$ antagonist and $\mathrm{D}_{2} \mathrm{R}$ availability described by (Sander et al, 2013) in preclinical models also exists in vivo in humans. Furthermore, we have shown that the relationship between ASL-CBF increases after antipsychotic administration also matched $\left[{ }^{18} \mathrm{~F}\right]$ Fallypride $\mathrm{BP}_{\mathrm{ND}}$ values in extra-striatal ROIs significantly populated by $\mathrm{D}_{2} \mathrm{R}$ such as the thalamus and the amygdala, even though they show lower $\mathrm{BP}_{\mathrm{ND}}$ values as compared with striatal ROIs. These results extend earlier evidence (Sander et al, 2013; 2016b) and suggest that the linear coupling between $\mathrm{CBF}$ response to dopaminergic drugs and $\mathrm{D}_{2} \mathrm{R}$ concentration might also be a valid model outside the striatum. This interpretation is also supported by the weaker correlation of $\Delta \mathrm{CBF}$ with $\left[{ }^{11} \mathrm{C}\right]$ raclopride $\mathrm{BP}_{\mathrm{ND}}$ as compared with $\left[{ }^{18} \mathrm{~F}\right] \mathrm{Fallypride}$ $\mathrm{BP}_{\mathrm{ND}}$ (Supplementary Material). 


\section{Microarray mRNA expression data}

We found that for all antipsychotics, the $\triangle \mathrm{CBF}$ profiles also correlated with microarray mRNA expression data extracted from the ABA. All genomic correlations were positive and therefore in the same direction of $\left[{ }^{18} \mathrm{~F}\right]$ Fallypride $\mathrm{BP}_{\mathrm{ND}}$ linear models. Notably, microarray mRNA expression measures explained less variance in $\triangle \mathrm{CBF}$ than $\left[{ }^{18} \mathrm{~F}\right] \mathrm{Fallypride} \mathrm{BP}_{\mathrm{ND}}$ values. This is consistent with our hypothesis motivated by the existence of a large variability between mRNA expression and protein synthesis due to post-transcriptional regulation mechanisms (Liu et al, 2016). Our findings are consistent with previous works that have linked the spatial architecture of the brain transcriptome to brain structure (Grecchi et al, 2017; Veronese et al, 2015), function (Hawrylycz et al, 2015; Richiardi et al, 2015) and in vivo measures of brain proteins (Gryglewski et al, 2018; Rizzo et al, 2014; 2016; Veronese et al, 2016a). Here we could show that post mortem brain mRNA expression data may potentially be used to map also variations in MRI-based functional response to drug stimulation. However, such mapping has still many limitations to be addressed in order to adopt it extensively in the context of pharmacological-MRI studies. For instance, it might be difficult to use mRNA expression mapping in neurotransmitter systems where protein synthesis is highly dependent on post-transcriptional regulation mechanisms (e.g. serotonin system) (Beliveau et al, 2017; Rizzo et al, 2014). While further studies are needed to fully validate this mRNA expression-MRI approach, it might be especially valuable for profiling the functional effects of drugs with poorly characterized or unknown targets. Interestingly, as for the correlation with receptor density profiles, the rank order of correlations between $\triangle \mathrm{CBF}$ and $D R D 2$ mRNA expression measures mirrored affinity profiles of the compounds, although these differences were only numerical. It is worth noting that the variance explained by genomic correlation was lower than the PET correlations (Table 1), which 
might have reduced the chance of detecting any significant difference on the pairwise comparison between the correlation coefficients.

These findings represent a further evidence supporting the hypothesized PK/PD model of antipsychotic effect of CBF measures (Mandeville et al, 2013; Sander et al, 2013). Indeed, we were able to show that quantitative measures of brain functional effect of antipsychotics (i.e. $\mathrm{CBF}$ changes) are directly associated with receptor density measures evaluated at different scales: mRNA expression and protein density.

\section{Differential strength of association between $\triangle \mathrm{CBF}$ and receptor density profiles.}

The correlation strength between $\triangle \mathrm{CBF}$ and receptor density measured with PET varied between the different antipsychotics tested. One possible interpretation of this difference might be related to the differential affinities for these compounds to $\mathrm{D}_{2} \mathrm{R}$ (Dukart et al, 2018). Our data seems to be in line with this hypothesis. In fact, the strengths of the association were higher for antipsychotics with higher affinity for $\mathrm{D}_{2} \mathrm{R}$ (Table 1 and Figure $\mathrm{S} 1$ ). In particular, HAL was the drug with the highest correlation coefficient and the lowest $\mathrm{Ki}$, whereas OLA showed the lowest correlation coefficient and the highest Ki. Both lowRIS and highRIS were in the middle between HAL and OLA. Another possible interpretation might be that related with the different secondary affinities between the drugs. For instance, for compounds with an high affinity with 5HT2a receptors like risperidone and olanzapine, part of the effect on CBF might also be linked with a mechanism different from $\mathrm{D}_{2} \mathrm{R}$ blockade (Goozee et al, 2014). Nonetheless, differences in brain disposition of antipsychotics have been reported in previous studies (Kornhuber et al, 2006; Rodda et al, 2006). In particular, animal data suggested that antipsychotics (including the ones considered in the present work) show different blood-brain barrier penetration and brain clearance leading to dissimilar spatial distribution in the brain (Loryan et al, 2016). Even though these dissimilarities have been 
reported to be only moderate (Loryan et al, 2016), brain disposition is a factor to be considered in addition to receptor affinity when linking the pharmacodynamics of each antipsychotic with receptor occupancy. Therefore, without maps of brain deposition variation, conclusions regarding the $\mathrm{D}_{2} \mathrm{R}$ affinities and strength of associations between receptors and $\mathrm{CBF}$ are necessarily incomplete.

\section{Limitations}

A number of limitations need to be considered for the present study. First, we used population-based profiles of $\mathrm{D}_{2} \mathrm{R}$ density as the spatial architecture of $\mathrm{D}_{2} \mathrm{R}$ is typically consistent across individuals (Rizzo et al, 2014; Veronese et al, 2016b). For example, the striatum always has higher $\mathrm{D}_{2} \mathrm{R}$ density than the thalamus which in turn has higher $\mathrm{D}_{2} \mathrm{R}$ density than the cortex. However, variance in density between individuals within the same brain region (Farde et al, 1995) may drive inter-individual differences in the drug functional response. Individualized receptor profiles mapping is therefore necessary to bring more precision to the method and to further validate the present findings. Nevertheless, normative atlases for protein and mRNA expressions have proven useful in many different applications, suggesting that the core spatial architecture of the brain receptor systems is consistent across individuals (Beliveau et al, 2017; Rizzo et al, 2014; 2016; Veronese et al, 2016b).

In addition, we considered only local effects by matching $C B F$ changes and $\mathrm{D}_{2} \mathrm{R}$ receptor density measures with the same ROIs. However, studies in patients and healthy volunteers showed that antipsychotics also produce changes in functional connectivity in rs-fMRI suggesting the existence of downstream effects (Cole et al, 2013; Sarpal et al, 2015) that were not included in our analyses.

As discussed above, increases in CBF after acute antipsychotic challenge have been usually interpreted as the result of a neuronal metabolic changes due to $\mathrm{D}_{2} \mathrm{R}$ blockade. However, 
$\mathrm{D}_{2} \mathrm{Rs}$ are also present in perivascular astrocytes modulating brain hemodynamic changes (Choi et al, 2006). In addition, both risperidone and olanzapine, but not haloperidol, act as antagonists at the serotonin-2a receptors (5HT2a) (Meltzer, 1999). Blockade of 5HT2a receptors on smooth-muscle cells of brain arteries has been shown to induce relative vasodilation in animal models (i.e. blocking vasoconstriction caused by the endogenous ligand serotonin) (Kovács et al, 2012). Therefore, the degree to which these non-neuronal effects contribute to the associations described here is not known.

\section{Conclusion}

Understanding the link between neurochemical changes and brain function is crucial to uncover mechanisms underlining the effects of psychopharmacological treatment and between-subjects variability in response. In this work we investigated the case of antipsychotics whose functional effect, evaluated as changes in CBF measures, mirror the well-known spatial distributions of their main target (i.e. $D_{2} R$ ). The characterisation of the haemodynamic response using this multimodal approach might be applicable also for other classes of drugs and it becomes particularly valuable for profiling compounds known to bind to multiple targets or with unknown or poorly characterised targets. Finally, our work demonstrates that the use of MRI 3D pCASL as a measure of regional CBF offers an efficient, non-invasive tool to investigate CNS penetration in the process of psychotropic drug development that is also linked with brain chemistry. 
Contract grant sponsor: Hoffmann - LaRoche Pharmaceuticals.

This paper represents independent research part funded by the National Institute for Health Research (NIHR) Biomedical Research Centre at South London and Maudsley NHS Foundation Trust and King's College London that support PS, OD, SCRW, FZ, MV and MAM. The views expressed are those of the authors and not necessarily those of the NHS, the NIHR or the Department of Health and Social Care. PS is supported by a PhD studentship jointly funded by the NIHR-BRC at SLaM and the Department of Neuroimaging, King's College London.

$\mathrm{AB}$ is a stockholder of Hoffmann-La Roche Ltd. He has also received consulting fees from Biogen and lecture fees from Otsuka, Janssen, Lundbeck. FS is a former employee of F. Hoffmann-La Roche Ltd.GP has been the academic supervisor of a Roche collaboration grant (years 2015-16) that funds his salary. JD is current employees of F. Hoffmann-La Roche Ltd. and received support in form of salaries. SCRW has received grant funding from the Medical Research Council (UK), Wellcome Trust (UK), National Institute for Health Research (UK) and support for investigator led studies from Takeda, Pfizer, Lundbeck, P1Vital, Roche and Eli Lilly. In the past 3 years MAM has acted as an advisory board member for Lundbeck and Forum Pharmaceuticals. He also holds research funding from Lundbeck, Takeda and Johnson \& Johnson. No other conflict of interested are disclosed.

\section{Acknowledgments}

MRI data were collected at the NIHR/Wellcome Trust King's Clinical Research Facility (CRF). Authors are grateful to the CRF team and to Dr Ndabezinhle Mazibuko and Stephanie Stephenson (Department of Neuroimaging, Institute of Psychiatry, Psychology and Neuroscience, King's College London, London, United Kingdom) for their help on data acquisition. We also gratefully acknowledge the work of Dr Joel Dunn (Kings College London and Guy's and St Thomas' PET Centre, School of Biomedical Engineering and Imaging Sciences, King's College London, London, UK) who contributed to the creation of PET templates. We also thank Gil Brown (London College of Communication, UAL London, UK) for her help on illustrations. Finally, we thank all the volunteers who took part in the study.

Supplementary information is available at the Neuropsychopharmacology website 


\section{References}

Agid O, Mamo D, Ginovart N, Vitcu I, Wilson AA, Zipursky RB, et al (2007). Striatal Vs Extrastriatal Dopamine D2 Receptors in Antipsychotic Response|[mdash]|A DoubleBlind PET Study in Schizophrenia. Neuropsychopharmacology 32: 1209-1215.

Attwell D, Iadecola C (2002). The neural basis of functional brain imaging signals. Trends in Neurosciences 25: 621-625.

Beliveau V, Ganz M, Feng L, Ozenne B, Højgaard L, Fisher PM, et al (2017). A HighResolution In Vivo Atlas of the Human Brain's Serotonin System. Journal of Neuroscience 37: 120-128.

Burt DR, Creese I, Snyder SH (1977). Antischizophrenic drugs: chronic treatment elevates dopamine receptor binding in brain. Science.

Choi J-K, Chen YI, Hamel E, Jenkins BG (2006). Brain hemodynamic changes mediated by dopamine receptors: Role of the cerebral microvasculature in dopamine-mediated neurovascular coupling. NeuroImage 30: 700-712.

Clark AJ (Springer Berlin Heidelberg: Berlin, Heidelberg, 1970). Methods of General Pharmacology. General Pharmacology 4-10doi:10.1007/978-3-662-28641-8 2.

Cole DM, Oei NYL, Soeter RP, Both S, van Gerven JMA, Rombouts SARB, et al (2013). Dopamine-dependent architecture of cortico-subcortical network connectivity. Cerebral Cortex 23: 1509-1516.

Cook RD, Weisberg S (1982). Residuals and influence in regression.

DeLisi LE, Holcomb HH, Cohen RM, Pickar D, Carpenter W, Morihisa JM, et al (1985). Positron emission tomography in schizophrenic patients with and without neuroleptic medication. J Cereb Blood Flow Metab 5: 201-206.

Desikan RS, Ségonne F, Fischl B, Quinn BT, Dickerson BC, Blacker D, et al (2006). An automated labeling system for subdividing the human cerebral cortex on MRI scans into gyral based regions of interest. NeuroImage 31: 968-980.

Dukart J, Holiga Š, Chatham C, Hawkins P, Forsyth A, McMillan R, et al (2018). Cerebral blood flow predicts differential neurotransmitter activity. Sci Rep 8: 4074.

Dunn JT, Stone J, Cleij M, Marsden PK, O'Doherty M, Reed LJ (2009). Differential occupancy of striatal versus extrastriatal dopamine D2/D3 receptors by the typical antipsychotic Haloperidol in man measured using [18F]-Fallypride PET. NeuroImage 47: S176.

Farde L, Hall H, Ehrin E, Sedvall G (1986). Quantitative analysis of D2 dopamine receptor binding in the living human brain by PET. Science 231: 258-261.

Farde L, Hall H, Pauli S, Halldin C (1995). Variability in $\mathrm{D}_{2}$-dopamine receptor density and affinity: A PET study with $\left[{ }^{11} \mathrm{C}\right]$ raclopride in man. Synapse 20: 200-208.

Fernández-Seara MA, Aznárez Sanado M, Mengual E, Irigoyen J, Heukamp F, Pastor MA (2011). Effects on resting cerebral blood flow and functional connectivity induced by metoclopramide: a perfusion MRI study in healthy volunteers. Br J Pharmacol 163: $1639-1652$.

Finch WH (2012). Distribution of variables by method of outlier detection. Front Psychol 3: 211.

Goozee R, Handley R, Kempton MJ, Dazzan P (2014). A systematic review and metaanalysis of the effects of antipsychotic medications on regional cerebral blood flow (rCBF) in schizophrenia: Association with response to treatment. Neuroscience \& Biobehavioral Reviews 43: 118-136.

Grecchi E, Doyle OM, Bertoldo A, Pavese N, Turkheimer FE (2014). Brain shaving: adaptive detection for brain PET data. Phys Med Biol 59: 2517-2534. 
Grecchi E, Veronese M, Bodini B, García-Lorenzo D, Battaglini M, Stankoff B, et al (2017). Multimodal partial volume correction: Application to [11C]PIB PET/MRI myelin imaging in multiple sclerosis. J Cereb Blood Flow Metab 37: 3803-3817.

Gryglewski G, Seiger R, James GM, Godbersen GM, Komorowski A, Unterholzner J, et al (2018). Spatial analysis and high resolution mapping of the human whole-brain transcriptome for integrative analysis in neuroimaging. NeuroImage doi:10.1016/j.neuroimage.2018.04.068.

Handley R, Zelaya FO, Reinders AATS, Marques TR, Mehta MA, O'Gorman R, et al (2013). Acute effects of single-dose aripiprazole and haloperidol on resting cerebral blood flow (rCBF) in the human brain. Hum Brain Mapp 34: 272-282.

Hawkins PCT, Wood TC, Vernon AC, Bertolino A, Sambataro F, Dukart J, et al (2018). An investigation of regional cerebral blood flow and tissue structure changes after acute administration of antipsychotics in healthy male volunteers. Hum Brain Mapp 39: 319331.

Hawrylycz M, Miller JA, Menon V, Feng D, Dolbeare T, Guillozet-Bongaarts AL, et al (2015). Canonical genetic signatures of the adult human brain. Nature Neuroscience 18: 1832-1844.

Hawrylycz MJ, Lein ES, Guillozet-Bongaarts AL, Shen EH, Ng L, Miller JA, et al (2012a). An anatomically comprehensive atlas of the adult human brain transcriptome. Nature 489: 391-399.

Hawrylycz MJ, Lein ES, Guillozet-Bongaarts AL, Shen EH, Ng L, Miller JA, et al (2012b). An anatomically comprehensive atlas of the adult human brain transcriptome. Nature 489: 391-399.

Heeger DJ, Ress D (2002). What does fMRI tell us about neuronal activity? Nat Rev Neurosci 3: 142-151.

Hertel P, Nomikos GG, Iurlo M, Svensson TH (1996). Risperidone: Regional effects in vivo on release and metabolism of dopamine and serotonin in the rat brain.

Psychopharmacology 124: 74-86.

Hoge RD, Atkinson J, Gill B, Crelier GR, Marrett S, Pike GB (1999). Linear coupling between cerebral blood flow and oxygen consumption in activated human cortex. Proc Natl Acad Sci USA 96: 9403-9408.

Holcomb HH, Cascella NG, Thaker GK, Medoff DR, Dannals RF, Tamminga CA (1996). Functional sites of neuroleptic drug action in the human brain: PET/FDG studies with and without haloperidol. Am J Psychiatry 153: 41-49.

Ichise M, Liow J-S, Lu J-Q, Takano A, Model K, Toyama H, et al (2003). Linearized reference tissue parametric imaging methods: application to [11C]DASB positron emission tomography studies of the serotonin transporter in human brain. J Cereb Blood Flow Metab 23: 1096-1112.

Ito H, Takano H, Takahashi H, Arakawa R, Miyoshi M, Kodaka F, et al (2009). Effects of the Antipsychotic Risperidone on Dopamine Synthesis in Human Brain Measured by Positron Emission Tomography with L-[ -11C]DOPA: A Stabilizing Effect for Dopaminergic Neurotransmission? J Neurosci 29: 13730-13734.

Kapur S, Remington G, Zipursky RB, Wilson AA, Houle S (1995). The D2 dopamine receptor occupancy of risperidone and its relationship to extrapyramidal symptoms: A pet study. Life Sciences 57: PL103-PL107.

Kapur S, Zipursky R, Jones C, Remington G, Houle S (2000). Relationship Between Dopamine D2 Occupancy, Clinical Response, and Side Effects: A Double-Blind PET Study of First-Episode Schizophrenia. American Journal of Psychiatry 157: 514-520.

Khalili-Mahani N, Rombouts SARB, van Osch MJP, Duff EP, Carbonell F, Nickerson LD, et al (2017). Biomarkers, designs, and interpretations of resting-state fMRI in translational 
pharmacological research: A review of state-of-the-Art, challenges, and opportunities for studying brain chemistry. Hum Brain Mapp 38: 2276-2325.

Kim E, Howes OD, Turkheimer FE, Kim BH, Jeong JM, Kim JW, et al (2013). The relationship between antipsychotic D2 occupancy and change in frontal metabolism and working memory : A dual [(11)C]raclopride and [(18)F]FDG imaging study with aripiprazole. Psychopharmacology 227: 221-229.

Kornhuber J, Wiltfang J, Riederer P, Bleich S (2006). Neuroleptic drugs in the human brain: clinical impact of persistence and region-specific distribution. Eur Arch Psychiatry Clin Neurosci 256: 274-280.

Kovács A, Hársing LG, Szénási G (2012). Vasoconstrictor 5-HT receptors in the smooth muscle of the rat middle cerebral artery. Eur J Pharmacol 689: 160-164.

Krimer LS, Muly EC, Williams GV, Goldman-Rakic PS (1998). Dopaminergic regulation of cerebral cortical microcirculation. Nature Neuroscience 1: 286-289.

Lee IA, Preacher KJ (2013). Calculation for the test of the difference between two dependent correlations with one variable in common [Computer software]. Retrieved July 182016.

Liu Y, Beyer A, Aebersold R (2016). On the Dependency of Cellular Protein Levels on mRNA Abundance. Cell 165: 535-550.

Logothetis NK, Pauls J, Augath M, Trinath T, Oeltermann A (2001). Neurophysiological investigation of the basis of the fMRI signal. Nature 412: 150-157.

Loryan I, Melander E, Svensson M, Payan M, König F, Jansson B, et al (2016). In-depth neuropharmacokinetic analysis of antipsychotics based on a novel approach to estimate unbound target-site concentration in CNS regions: link to spatial receptor occupancy. Nature Publishing Group 21: 1527-1536.

Mandeville JB, Sander CYM, Jenkins BG, Hooker JM, Catana C, Vanduffel W, et al (2013). A receptor-based model for dopamine-induced fMRI signal. NeuroImage 75: 46-57.

McCormick PN, Kapur S, Graff-Guerrero A, Raymond R, Nobrega JN, Wilson AA (2010). The antipsychotics olanzapine, risperidone, clozapine, and haloperidol are D2-selective ex vivo but not in vitro. Neuropsychopharmacology 35: 1826-1835.

Mehta M (2003). Systemic sulpiride modulates striatal blood flow: relationships to spatial working memory and planning. NeuroImage 20: 1982-1994.

Meltzer HY (1999). The role of serotonin in antipsychotic drug action. Neuropsychopharmacology 21: 106S-115S.

Miller DD, Andreasen NC, O'Leary DS, Watkins GL, Boles Ponto LL, Hichwa RD (2001). Comparison of the effects of risperidone and haloperidol on regional cerebral blood flow in schizophrenia. BPS 49: 704-715.

Miller DD, Andreasen NC, O’Leary DS, Rezai K, Watkins L, Boles Ponto LL, et al (1997). Effect of antipsychotics on regional cerebral blood flow measured with positron emission tomography. Neuropsychopharmacology 17: 230-240.

Mukherjee J, Christian BT, Dunigan KA, Shi B, Narayanan TK, Satter M, et al (2002). Brain imaging of $18 \mathrm{~F}$-fallypride in normal volunteers: blood analysis, distribution, test-retest studies, and preliminary assessment of sensitivity to aging effects on dopamine D-2/D-3 receptors. Synapse 46: 170-188.

Mukherjee J, Yang Z-Y, Das MK, Brown T (1995). Fluorinated benzamide neuroleptics-III. Development of (S)-N-[(1-allyl-2-pyrrolidinyl)methyl]-5-(3-[18F]fluoropropyl)-2,3dimethoxybenzamide as an improved dopamine D-2 receptor tracer. Nuclear Medicine and Biology 22: 283-296.

Nyberg S, Farde L, Halldin C, Dahl ML (1995). D2 dopamine receptor occupancy during low-dose treatment with haloperidol decanoate. American Journal of ....

Ploeger BA, van der GRAAF PH, and MDDM, 2009 (2009). Incorporating receptor theory in mechanism-based pharmacokinetic-pharmacodynamic (PK-PD) modeling. Elsevier 
24: $3-15$.

Richiardi J, Altmann A, Milazzo AC, Chang C (2015). Correlated gene expression supports synchronous activity in brain networks. Science 348: 1241-1244.

Rizzo G, Veronese M, Expert P, Turkheimer FE, Bertoldo A (2016). MENGA: A New Comprehensive Tool for the Integration of Neuroimaging Data and the Allen Human Brain Transcriptome Atlas. PLoS ONE 11: e0148744-20.

Rizzo G, Veronese M, Heckemann RA, Selvaraj S, Howes OD, Hammers A, et al (2014). The predictive power of brain mRNA mappings for in vivo protein density: a positron emission tomography correlation study. Journal of Cerebral Blood Flow \&amp; Metabolism 34: 827-835.

Rodda KE, Dean B, McIntyre IM, Drummer OH (2006). Brain distribution of selected antipsychotics in schizophrenia. Forensic Sci Int 157: 121-130.

Sander CY, Hooker JM, Catana C, Normandin MD, Alpert NM, Knudsen GM, et al (2013). Neurovascular coupling to D2/D3 dopamine receptor occupancy using simultaneous PET/functional MRI. Proc Natl Acad Sci USA 1-6doi:10.1073/pnas.1220512110//DCSupplemental.

Sander CY, Hooker JM, Catana C, Rosen BR, Mandeville JB (2016a). Imaging AgonistInduced D2/D3 Receptor Desensitization and Internalization $<\mathrm{i}>$ In Vivo $</ \mathrm{i}>$ with PET/fMRI. Neuropsychopharmacology 41: 1427-1436.

Sander CY, Hooker JM, Catana C, Rosen BR, Mandeville JB (2016b). Imaging AgonistInduced D2/D3 Receptor Desensitization and Internalization $<\mathrm{i}>$ In Vivo $</ \mathbf{i}>$ with PET/fMRI. Neuropsychopharmacology 41: 1427-1436.

Sarpal DK, Robinson DG, Lencz T, Argyelan M, Ikuta T, Karlsgodt K, et al (2015). Antipsychotic treatment and functional connectivity of the striatum in first-episode schizophrenia. JAMA Psychiatry 72: 5-13.

Singh KD (2012). Which "neural activity" do you mean? fMRI, MEG, oscillations and neurotransmitters. NeuroImage 62: 1121-1130.

Stark AJ, Smith CT, Petersen KJ, Trujillo P, van Wouwe NC, Donahue MJ, et al (2018). $[18 \mathrm{~F}]$ fallypride characterization of striatal and extrastriatal D2/3 receptors in Parkinson's disease. YNICL 1-42doi:10.1016/j.nicl.2018.02.010.

Stroup TS, Lieberman JA, McEvoy JP, Davis SM, Swartz MS, Keefe RSE, et al (2009). Results of phase 3 of the CATIE schizophrenia trial. Schizophrenia Research 107: 1-12.

Tabachnick BG, Fidell LS (2013). Using Multivariate Statistics.

Tauscher J, Hussain T, Agid O, Verhoeff NPLG, Wilson AA, Houle S, et al (2004). Equivalent Occupancy of Dopamine D1 and D2 Receptors With Clozapine: Differentiation From Other Atypical Antipsychotics. American Journal of Psychiatry 161: $1620-1625$.

Vernaleken I, Kumakura Y, Buchholz H-G, Siessmeier T, Hilgers R-D, Bartenstein P, et al (2008). Baseline $\left[{ }^{18} \mathrm{~F}\right]$-FDOPA kinetics are predictive of haloperidol-induced changes in dopamine turnover and cognitive performance: A positron emission tomography study in healthy subjects. NeuroImage 40: 1222-1231.

Veronese M, Bodini B, García-Lorenzo D, Battaglini M, Bongarzone S, Comtat C, et al (2015). Quantification of [(11)C]PIB PET for imaging myelin in the human brain: a testretest reproducibility study in high-resolution research tomography. Journal of Cerebral Blood Flow \&amp; Metabolism 35: 1771-1782.

Veronese M, Zanotti-Fregonara P, Rizzo G, Bertoldo A, Innis RB, Turkheimer FE (2016a). Measuring specific receptor binding of a PET radioligand in human brain without pharmacological blockade: The genomic plot. NeuroImage 130: 1-12. 
Veronese M, Zanotti-Fregonara P, Rizzo G, Bertoldo A, Innis RB, Turkheimer FE (2016b). Measuring specific receptor binding of a PET radioligand in human brain without pharmacological blockade: The genomic plot. NeuroImage 130: 1-12.

Viviani R, Graf H, Wiegers M, Abler B (2013). Effects of amisulpride on human resting cerebral perfusion. Psychopharmacology 229: 95-103.

Viviani R, Sim E-J, Lo H, Richter S, Haffer S, Osterfeld N, et al (2009). Components of variance in brain perfusion and the design of studies of individual differences: The baseline study. NeuroImage 46: 12-22. 
Figure 1. General framework of the analysis. Group-level map showing main effect of drug was computed for each antipsychotic. The resulting maps and the 18F]Fallypride PET template were segmented into 83 ROIs by using the Desikan-Killiany Atlas (Desikan et al, 2006). For each ROI $\triangle$ CBF profiles and [18F]Fallypride BPND values were extracted and then correlated. DRD2 gene brain microarray mRNA expression values were extracted from ABA data (http://human.brain-map.org) (Hawrylycz et al, 2012b). MENGA software (http://www.nitrc.org/projects/menga/) (Rizzo et al, 2016) was used to extract DRD2 mRNA expression profiles which then entered multivariate correlation analysis against $\triangle \mathrm{CBF}$ profiles (please refer to methods section for a more detailed description).

Figure 2. Scatterplots of $\triangle \mathrm{CBF} /$ receptor density profiles correlations. Top row: scatterplot of the correlation between HAL $\triangle \mathrm{CBF}$ profiles and [18F]Fallypride BPND (left) and of the correlation between OLA $\triangle \mathrm{CBF}$ profiles and [18F]Fallypride BPND (right). Bottom row: scatterplot of the correlation between lowRIS $\triangle \mathrm{CBF}$ profiles and [18F]Fallypride BPND (left) and of the correlation between highRIS $\triangle \mathrm{CBF}$ profiles and [18F]Fallypride BPND (right). Dashed lines indicate 95\% confidence bands.

Figure 3. Scatterplots of the genomic correlation. For all scatterplots on the y axis normalized DRUG $>$ PLACEBO CBF changes and on the $\mathrm{x}$ axis DRUG $>$ PLACEBO CBF changes predicted by the first Principal Component of the mRNA expression measures of the 6 ABA donors. Top right: HAL; Top left: OLA; Bottom right: lowRIS; Bottom left: highRIS. Dashed lines indicate $95 \%$ confidence bands. 
D2 receptor

density profiles

[18F] Fallypride BP map
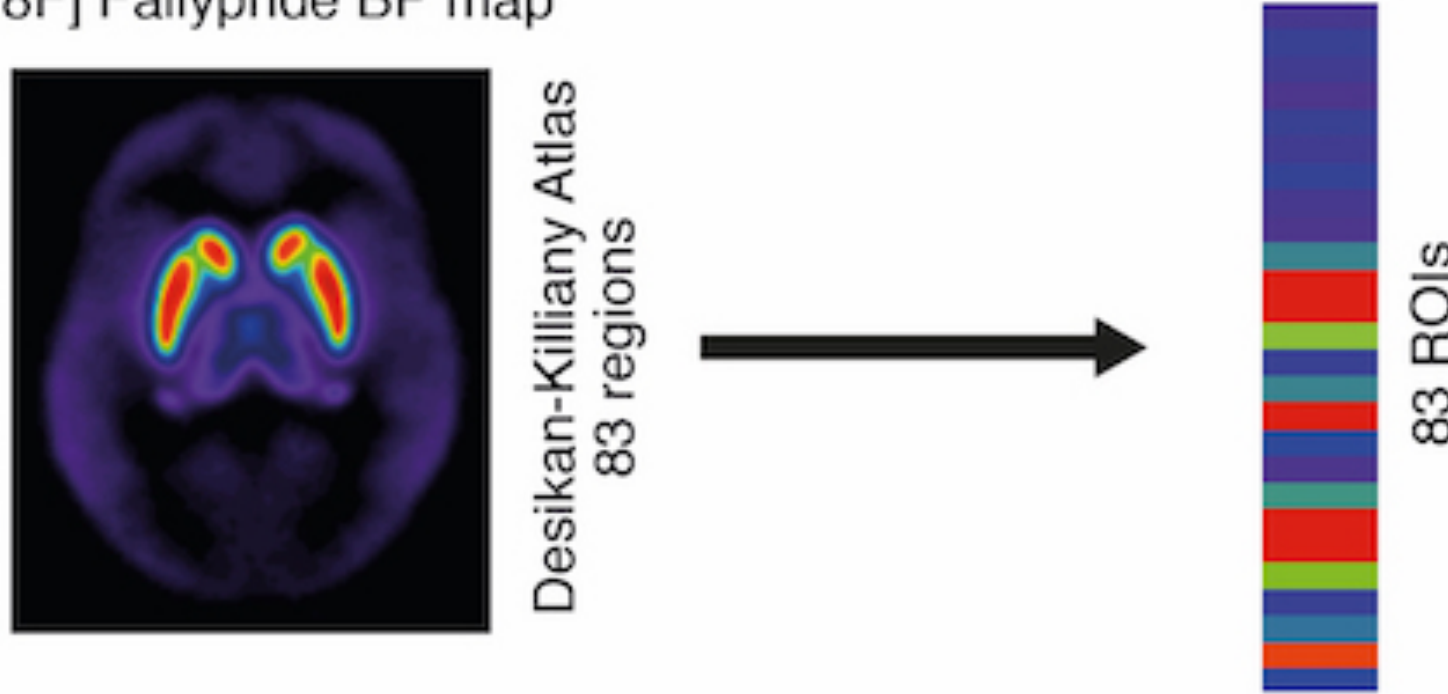

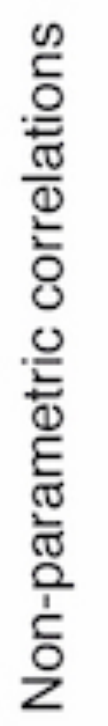

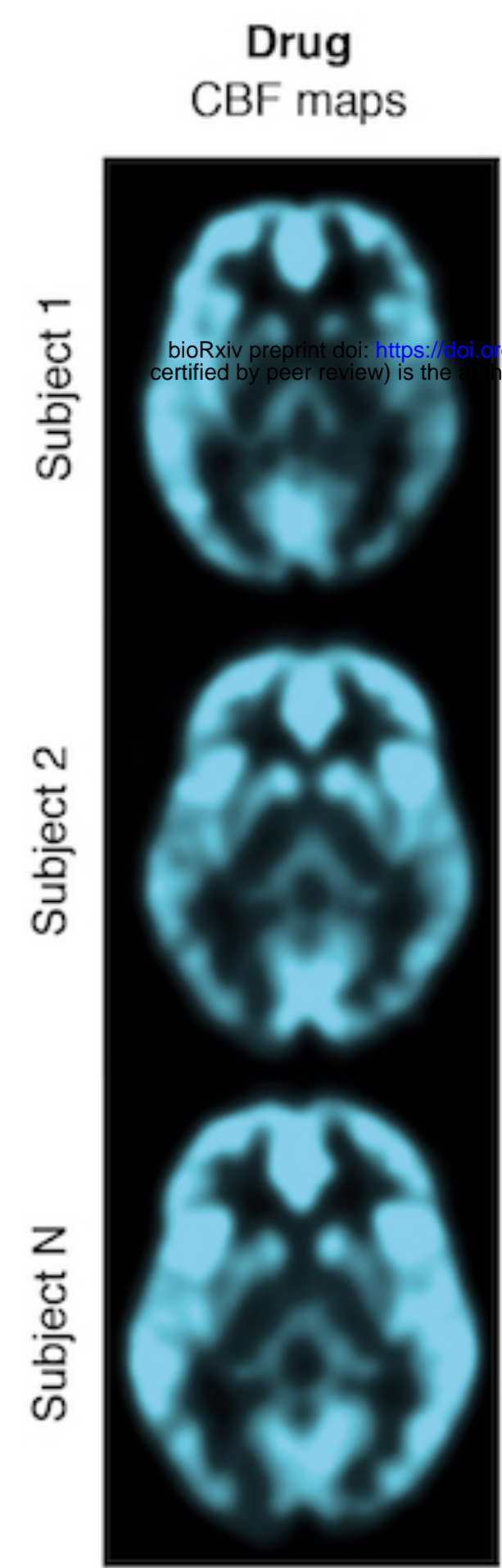

Placebo

CBF maps

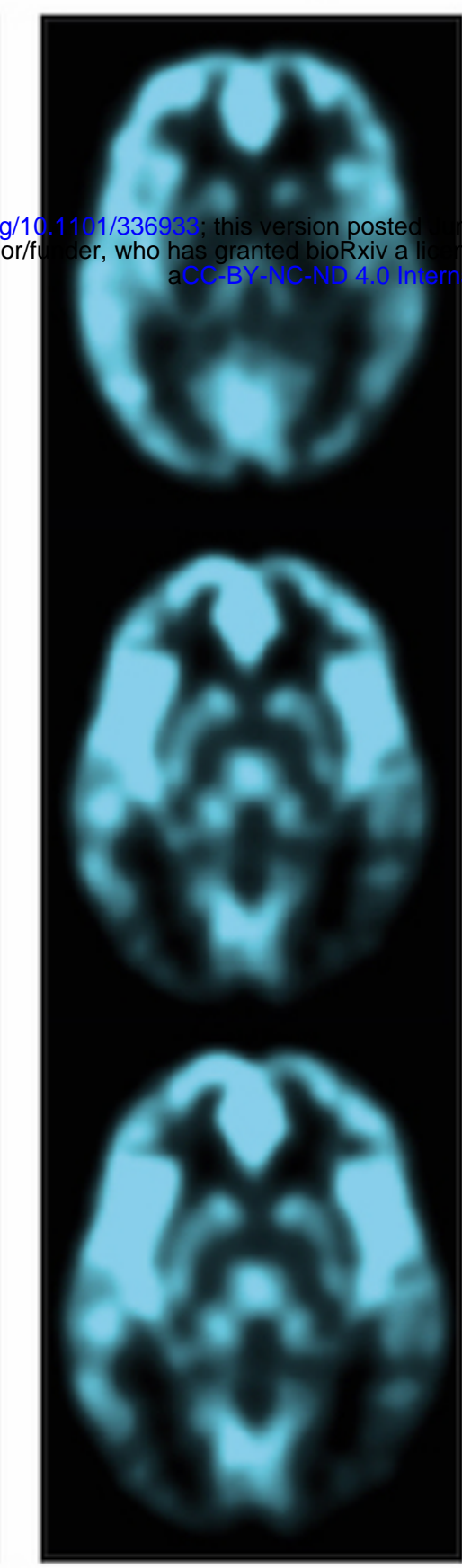

Group Drug > Placebo

Contrast images

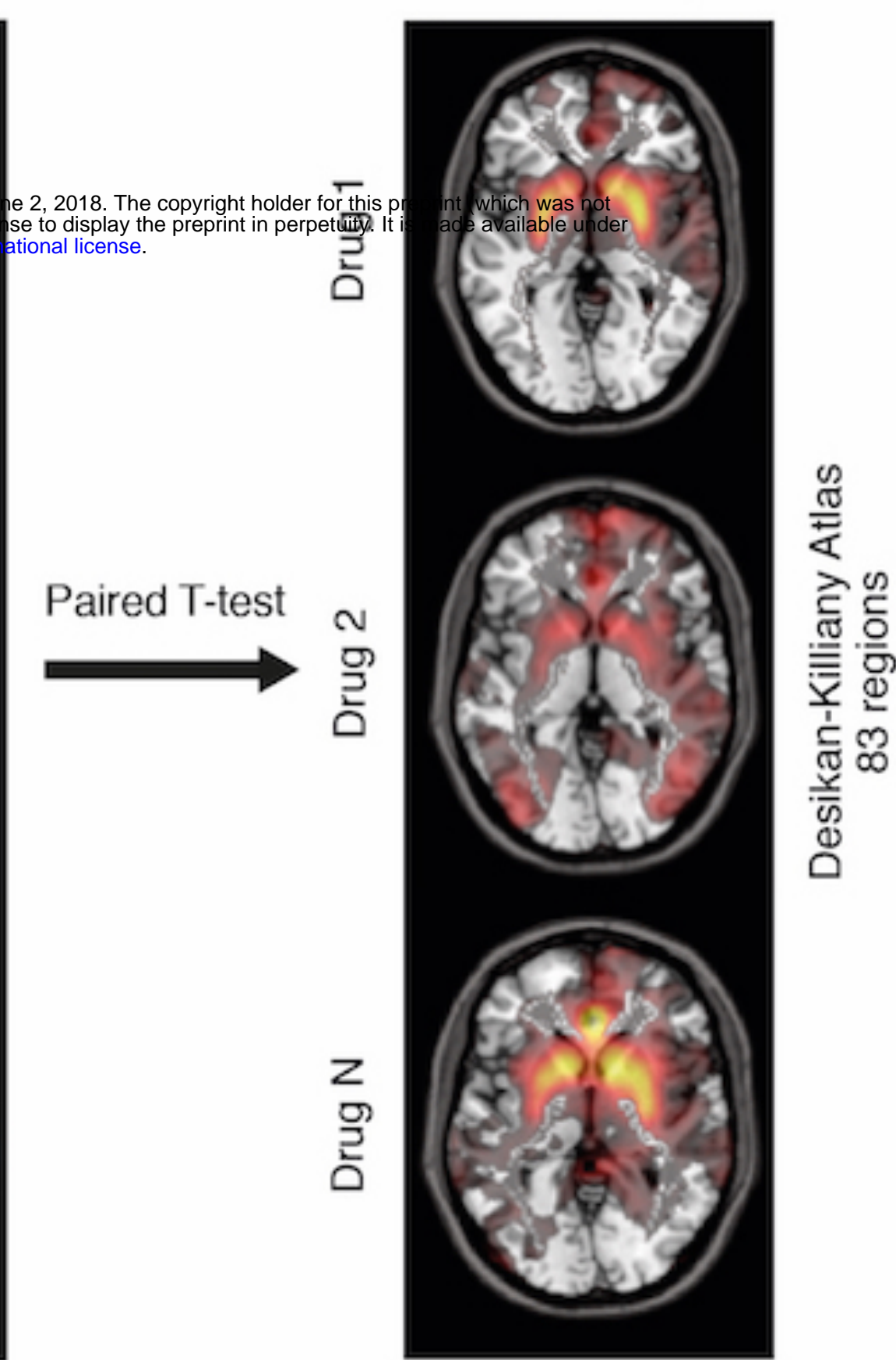

DRD2 mRNA

expression map
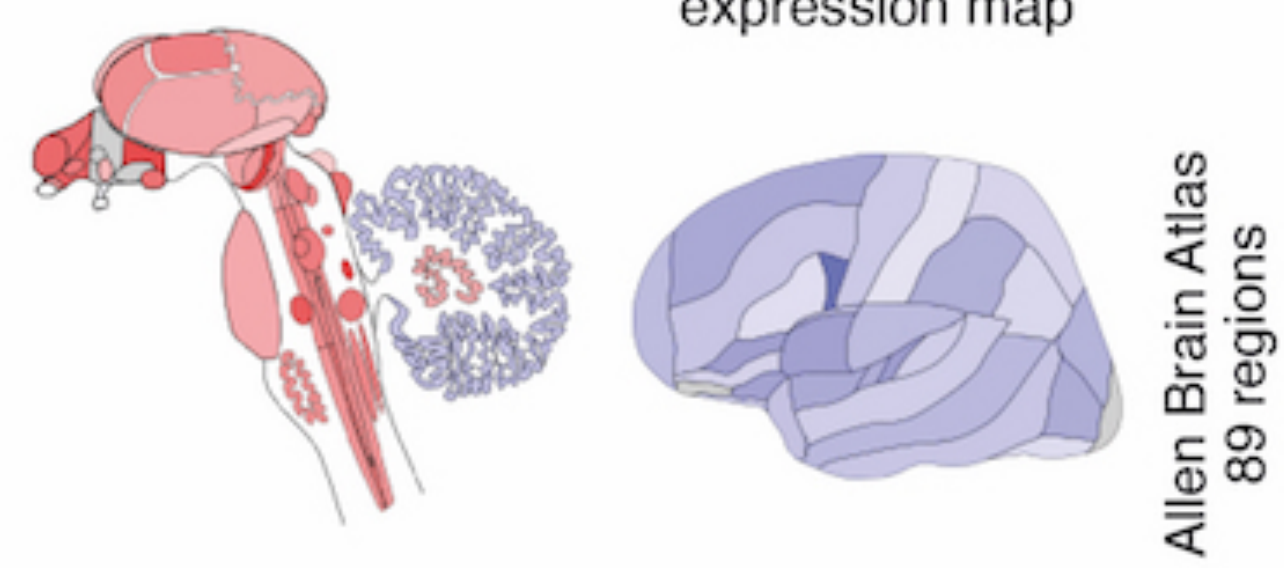

DRD2 mRNA expression profiles

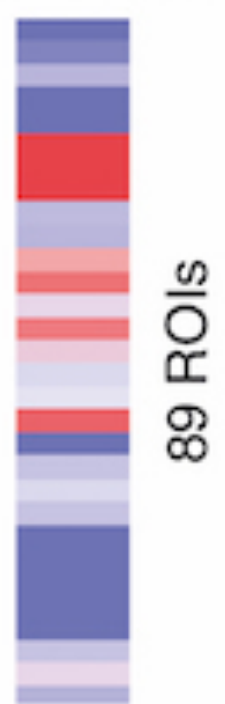

mRNA expression

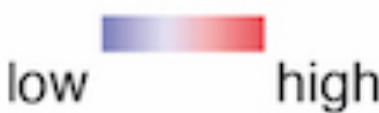



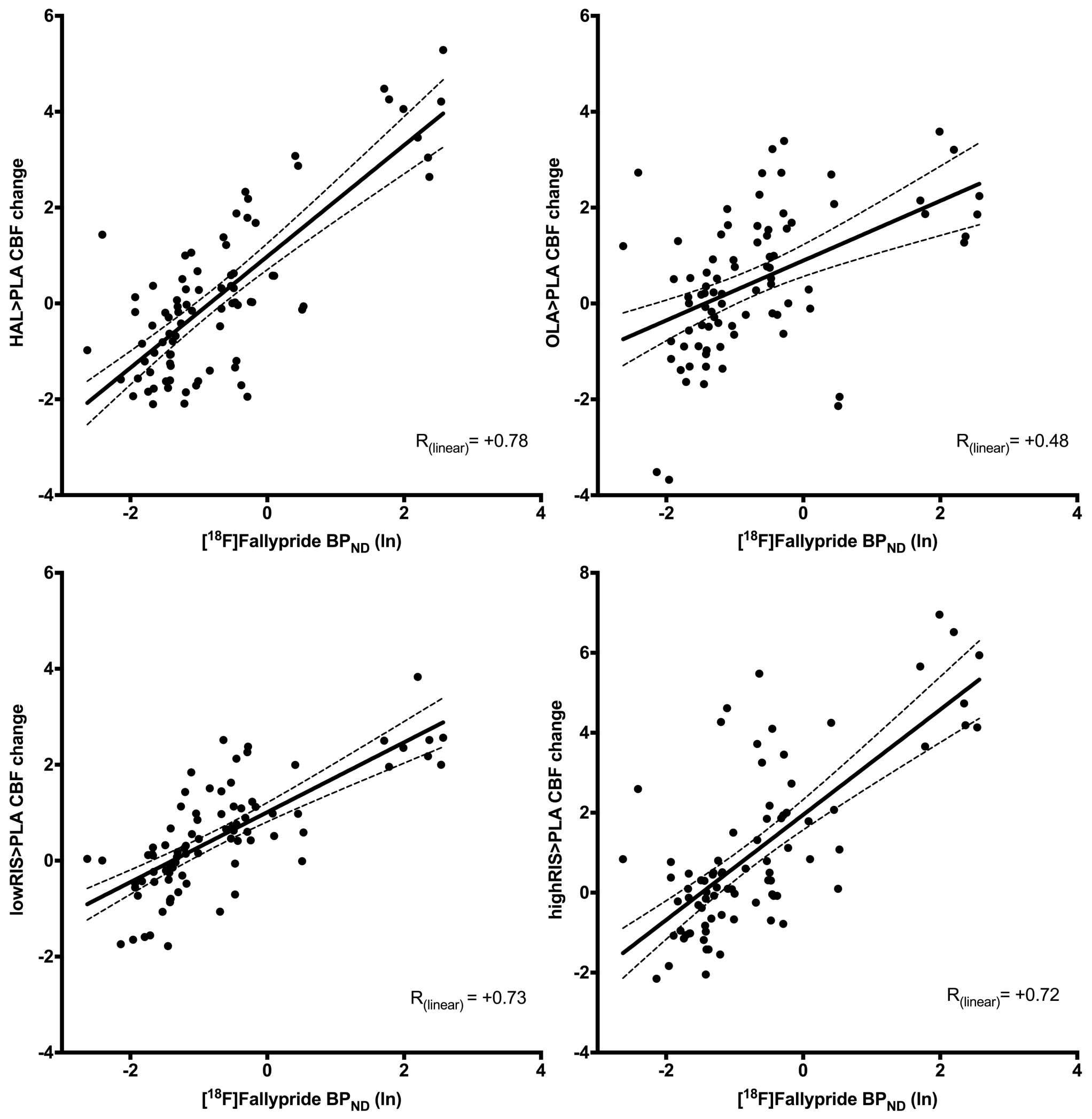

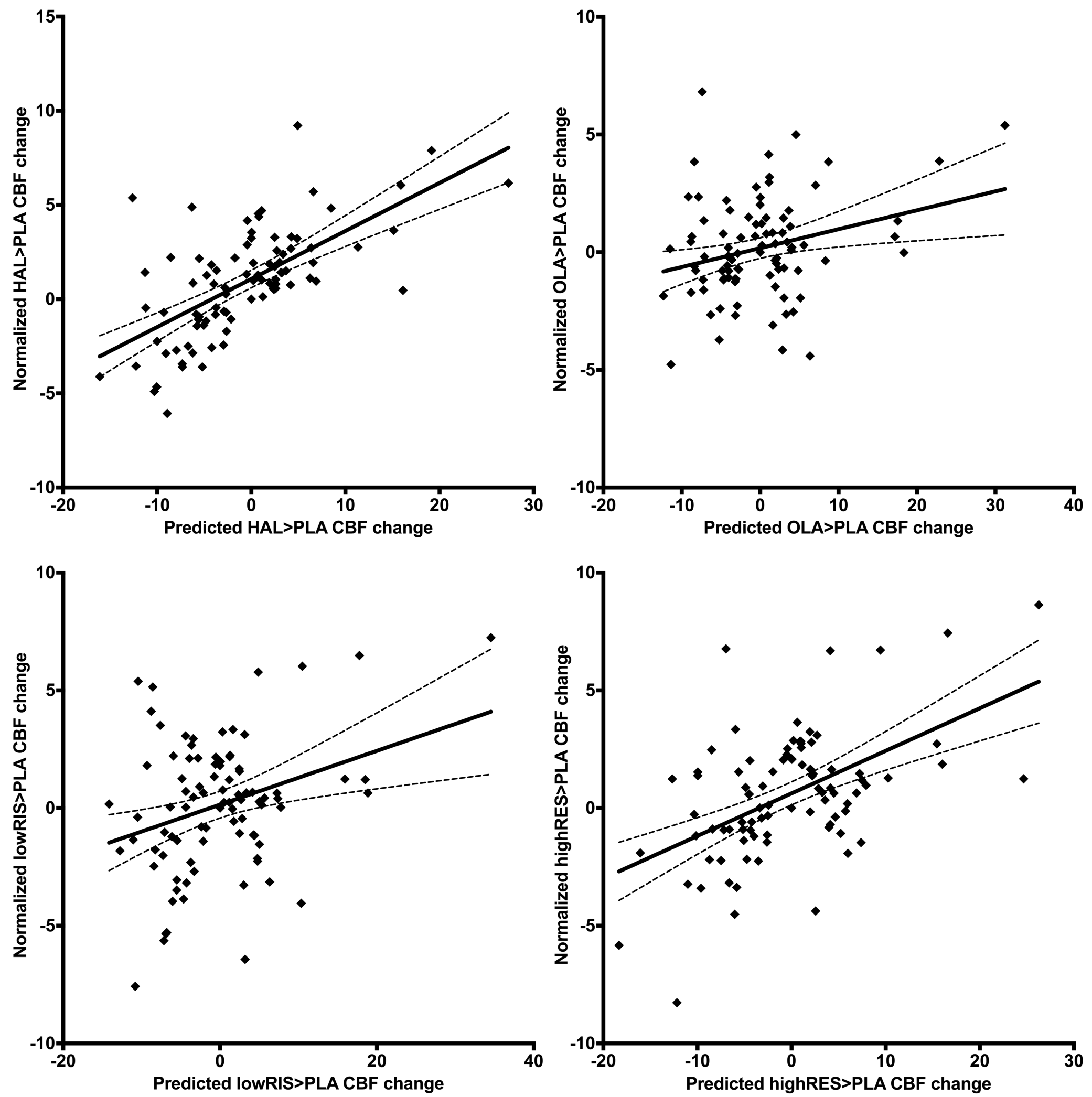
Table 1. Summary of the correlations of $\triangle \mathrm{CBF}$ profiles $\mathrm{D}_{2}$ receptor profiles $\left(\left[{ }^{18} \mathrm{~F}\right] \mathrm{Fallypride}\right.$ $\left.\mathrm{BP}_{\mathrm{ND}}\right)$ and of genomic multivariate cross-correlations of antipsychotics' $\Delta \mathrm{CBF}$ profiles with DRD2 mRNA expression profiles.

\begin{tabular}{|c|c|c|c|c|c|c|}
\hline \multirow[t]{2}{*}{$\begin{array}{c}\text { DRUG }>\text { PLA } \\
\text { contrast }\end{array}$} & \multicolumn{4}{|c|}{$\left[{ }^{18} \mathbf{F}\right]$ Fallypride $B P_{\mathrm{ND}}$} & \multicolumn{2}{|c|}{$\begin{array}{c}\text { DRD2 mRNA } \\
\text { expression }\end{array}$} \\
\hline & $\mathbf{R}_{\text {linear }}$ & p $_{\text {linear }}$ & Spearman rho & p Spearman & $\mathbf{R}$ & $\begin{array}{l}\text { Chance } \\
\text { likelihood }\end{array}$ \\
\hline HAL & +0.78 & $\mathrm{p}<0.001$ & 0.61 & $\mathrm{p}<0.001$ & +0.34 & $0 \%$ \\
\hline OLA & +0.48 & $\mathrm{p}<0.001$ & 0.51 & $\mathrm{p}<0.001$ & +0.21 & $0 \%$ \\
\hline lowRIS & +0.73 & $\mathrm{p}<0.001$ & 0.76 & $\mathrm{p}<0.001$ & +0.43 & $0 \%$ \\
\hline highRIS & +0.72 & $\mathrm{p}<0.001$ & 0.61 & $\mathrm{p}<0.001$ & +0.45 & $2 \%$ \\
\hline
\end{tabular}

